\title{
アムステルダムの都市計画の歴史—1917年の ベルラーへの南郊計画とアムステルダム派の意義
}

\author{
神奈川県都市部都汀計画課 正会員 越沢 明
}

\begin{abstract}
Planning History of Amsterdam and the Significance of the Southern Extension Plan (the Extension Plan "Zuid") by H.P.Berlage Approved in 1917
\end{abstract}

\section{by Aki ra KOSHIZAWA}

\section{概 琶}

欧米の近代都市計画の歴史については、一都市の全容を解明した奏証的な研觉は意外な ことに少ない。本稿はオランダの首都アムテルダルダムの歴史を取り上げている。

13 世紀に成立したアムテルダルダムはオランダが独立した17世紀初めに急激に発展 した。計画的に運河の開削と建築教地の造成が行われ、近代都市計画の先衫け（建築規則 の適用、超過收用の実施）が見られる。その後、19世紀後半、産業の近代化とともに市 街地の抾張が実施されたが、住宅の水準は低く、労働者住宅と都市インララの改良が都市 行政の大きな棵題となった。

市当局の依頼によりオランダを代表する建筑家ベルラーへが設計した市街拉張計画のう ち南郊地区が1915年より実施された。用地は河が買収し、住宅協会が集合住宅を建設した。 南郊地区には広幅貣街路、㕕埸、公圈、住宅、公其施設が吅みに配羁され、特に集合住宅

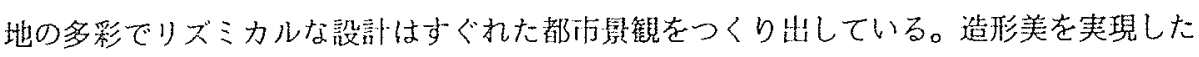
都计計画としてPlan "Zuid" の意義を今日、再評俩してよいと思われる。

\Key Words: Amsterdam, Plan "Zuid", II.P.Berlage, Amsterdam School】

\section{1 はじるに}

1850年代・60年代に実施されたセーヌ県知事オス マンによるパリ都汸改造は欧米における近代都市計 画の始まりであった。これ以隆、1930年代初めに至 るまで欧州の主姴都市（首都・州都クラスの都市） では旧泫街の改造と书街地の搪張が行われ、今日に 至っている。第二次世界大戦後の郊外の二ュータウ ン建設を除けば、欧州の主姴都沙の市街地形態と都 汿の社会資本はこの70年間の時期の都市基盤整備を もって確定している。しかし、オスマンのパリ都市

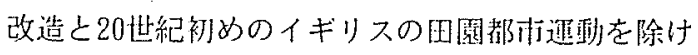
ば、欧州の近代都淤計画の実態については、日本語 の研究がほとんよ゙存在しないのが奏情である。そこ で本稿ではオランダの首都アムステルダムの都沁計 画の歷史を取り上げ、中でも都汸デザイン、景観設
部という点で今日でも学ぶべき点が多い。ベルラー へ(Dr. Il. P. Berlage) 設計の1917年南郊甫街搪張計 西 (The Extension Plan "Zuid") (1) について詳し く諭じることにしたい。

\section{2 アムステルダムの17世紀の都析計画}

ライン川左岸の低地地方（現在のオランダ）に中 世都淤が勃興したのは12〜13世紀のことである。ア ムステルダムもそのひとつであり、1275年、ホラン 卜伯より自治锥を付与された都市として誕生した。 ダム（オランダ語で满を意味する）という名称が示 すようにアムステル川の河口に運河をつくり、港湾 都市として成立したのがアムステルダムである。ア ムステルダムはバルト海貿易の拠点都市として成長 したが、当時、北部の低地地方は南部のフランドル 


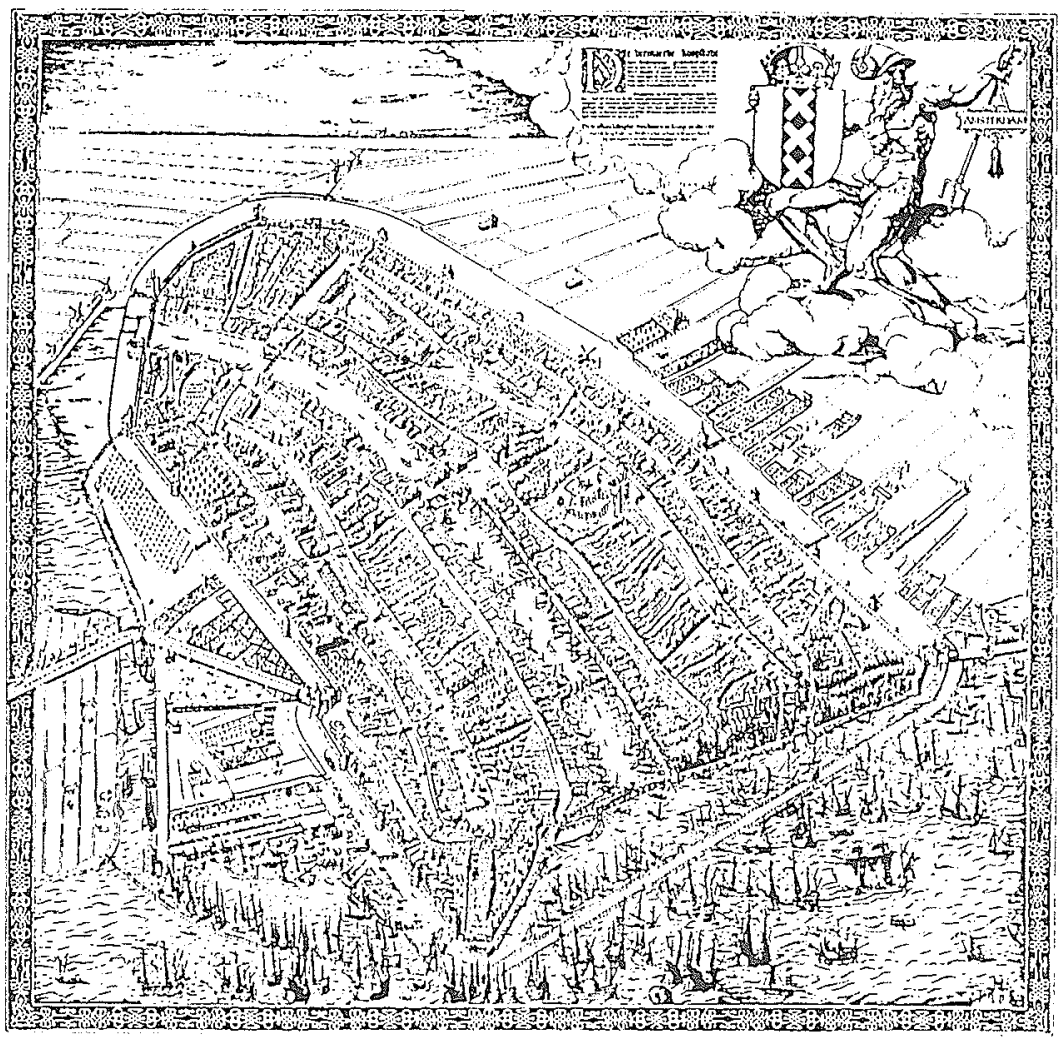

図11544 年のアムステルダム
Amslerdam in 1544 ,

drawn by Cornelis

Anthoniszoon. (In the bollom lefl-hand corner is the Lastage)

出所 文献 2

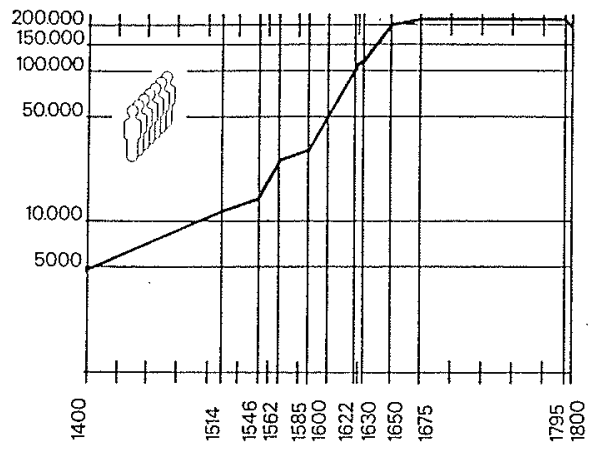

㘡 2 アムステルダムの人口推移（15 世紀～18 世紀）

地方（現在のベルギ一）に比へてて経済的な発展は立 ち遅れており、16世紀まで人口は数万人にすぎなか った（図1、図2）。

八十年戦争のさなか、1585年、当時西ヨーロッパ 最大の商港であったフランドル地方のアントワープ をスペイン軍が占領し、一方、オランダ軍がスヘル

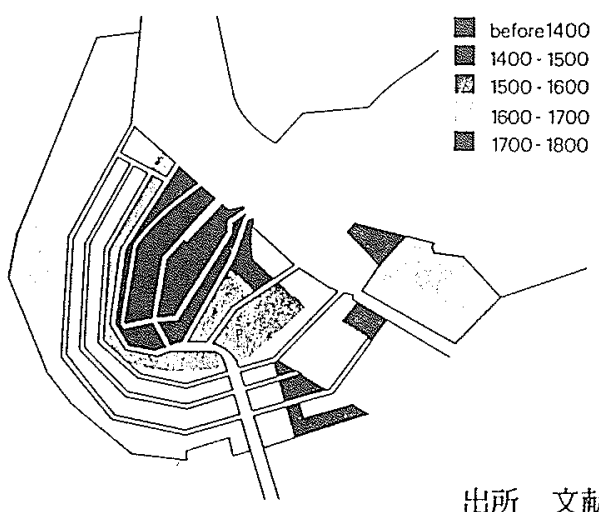

出所 文献 6

Left Population growth, 1400-1800. The graph rises increasingly steely until around 1650 and then levels off. 77 e figures are estimates.

Right Physical groweth, 1400-1800. The city exlensions are given al 100-year intervals. 7he period of greatest expansion woas between 1600 and 1650 . when the population was growing fastest.

図 3 アムステルダムの市街拡大 （15世紀～18 世紀） 


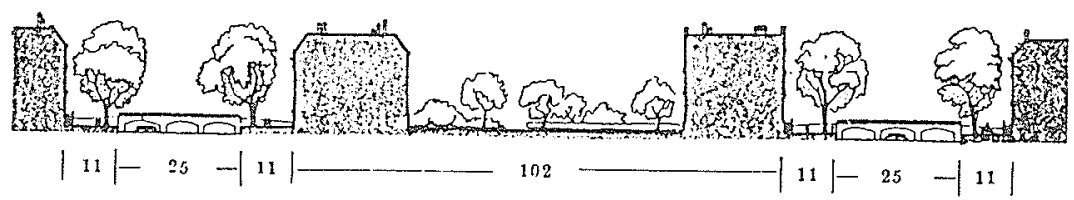

図4 1612〜25年に開㴥された通河と建築数地の断面

出所 文献11

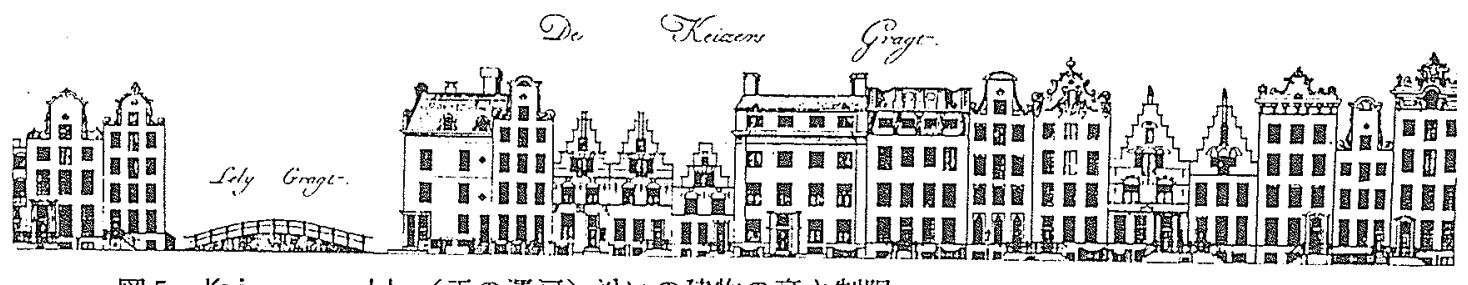

図 5 Kaizersgracht（王の蓮河）治いの建物の离さ制限

Strict building regulations
were laid down for
construclion along the
canals. (Drawing by
C. Philips)

出所 文献 2

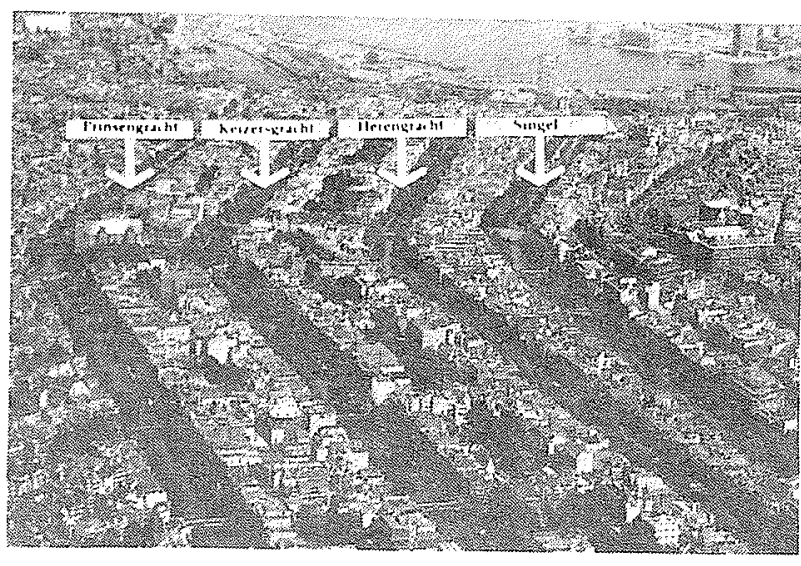

図 6 1612〜25年に開㴥された 通河一㠿の街立みの現沉

テ河口を䦥鎖したため、アントワープの貿易、㹍菜 は途絶した。このためアントワープの大墑人はアム ステルダムに移住した。これ以降、アムステルダム は新興国家オランダ（1581年に独立宣言、1588年に

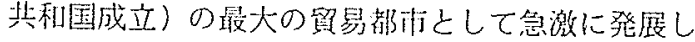
ていった。

1602年に迎合柬インド会社、1608年に阔菜の取引 形が設立され、ヨーロッパで最も先進的な㖬菜国家 の中心地——それがアムステルダムであった。

1570年には3万人にずかかった人口が1640年に は139,000人となり、1650年には20万人に達した。 この17世紀の急激な人口增加之同時に、涌域の抎張 が行われた（図2、図3）。
1612〜1625作、泫域の西侧に3本の同心円状の连 河 (llerengracht $=$ 貴族の迎河、Keizersgracht = 王 の運河、Prinsengracht＝王子の運河）が開削され、 通河に沿って它地が造成された。师政府は土地を取 用し、速河を開㴊し、運河沿いの建築䑤地を売却し 資金を回収した（これはオスマンのパリ都市改造の 手法二超過収用の先駆けである)。

建築㪙地の瞵入者は建築法規に則って建物を建て なければならなかった（図4）。運河の幅は $25 \mathrm{~m}$ (航路 4 艘分、うち 2 艘は航行用、2 艘は停船用) とし、運河の画側に幅 $11 \mathrm{~m}$ の河岸用地（荷役の用地

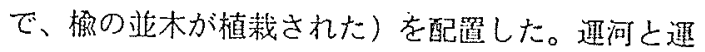
河の間には 2 列の建築謷地の区画（骨行は各51m) が配珇され、各建物の琵㑡には各 $24 \mathrm{~m}$ (計 $48 \mathrm{~m})$ の 奥行のオープンスペースを残さなければならなかっ た（図 5)。3本の遇河はそれ以前の運河とは異な り、直線状の形をしているが、これは運河治いの建 筑敷地を規則的な㸝状にするためであった（図 6)。

この17世紀初めの遇河開削・宅地造成はアムステ ルダムに抢ける最初の都市計画（計画的な市域㹡張 という意味で）であった。しかも、ヨーロッパの近 代都市訃画の代表的な事業手法である超過収用がす でにこのとき実施され、開発利益を公的還元する手 
法が採用されていたことは注目に値する。また建築

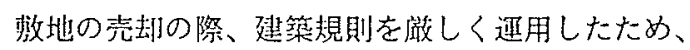
運河沿いに高さの揃った統一観のある街並みとなり、 速河治いの並木と相俟って今日、アムステルダム観 光の中心となる美しい都市景観が形成された。17世 紀初めの市域搪張は中世の古典的な都市計画の傑作 のひとつであると見做すことができるが、その中に はすでに近代都市計画の法制度やデザイン手法が芽 生えていたのである。このような近代都汁計画の手 法が芽生えた原因について、筆者はアムステルダム が国王の都ではなく、都市貴族・有力商人が支配す る商業の都であり、そのため都市計画の動機、課題 が宮殿や官庁街の建設にあるのではなく、商家や運 河・倉庫の建設にあったことにあると考えている。

1658〜1663年、アムステルダムの同心円状の運河 が市域の南側と東侧にも開削され、市域が拡張し、 その外周に城壁が築かれた。アムステル川以西の拡 張汸街には多数のユダヤ人移民が居住し、短期間で ビルトアップした。これに対して東侧の拡張市街 (Plantage地区) にはプロムナード公園と富裕市民 のための小さなカントリーハウスが整備された（市 より賃貸）。この公畦的な地区は19世紀末までビル トアップしなかった（カントリーハウスが撤去され た後、この地区の中心部分は1838年、Natura Artis Magistra協会が創設され、動物園が整備された）。

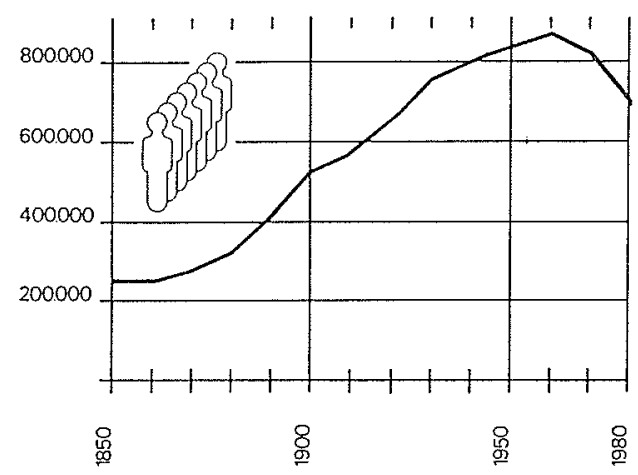

困７アムステルダムの人口推移（19世紀～２０世紀） 出所 文献 6
17世紀末、城壁内のアムステルタム市街は面積 800ha、人口21万人となり、ヨーロッパで第 4 の大都 市となっていた。

319 世紀のアムステルダムの近代化と都朽整備の 課題

17世紀末を繁篓のピークとしてこ机以降、アムス テルダムの人口は19世紀半ばまでほぼ一定で、停滞 の時代を迎える（図 2，図 7 ）。

17世紀末よりオランダはイギリス、フランスとの 戦争、抗争の中で経済为を失い、欧州貿易、植民地 貿易におけるアムステルダムの地位は低下した。ま た内海（ザイテル海）の土砂堆積によりアムステル ダムの港湾機能そのものも低下した。

しかし、19世紀半ばになると植民地貿男、加工業 による資本萻積が進み、一方、労働運動も開始され た。こうした中で1860年代、1870年代、オランダの 産䉾の近代化が始まり、アムステルダムの都市基盤 整備が再び開始された。

1848～1852年、アムステルダム西方の広大な湖沼 (llaar lemmermeer, 現在のスキポール空港用地 $=$ 18,500haはその極一部分である) が干拓され、アム ステルダムのヒンターラントを形成する農耕地が出

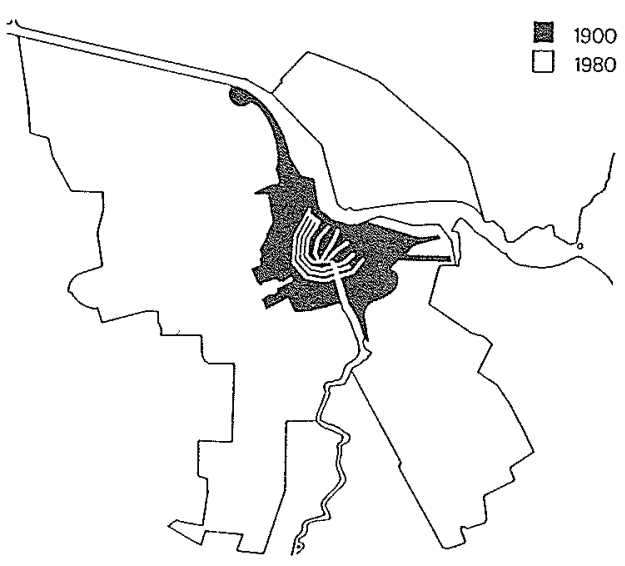

Left Population, 1850-1980

Right Amsterdam in 1900 and in 1980. 7 the final year also includes the ncighbouring developments in Amstelveen, Duivendrecht and Diemen.

図 8 アムステルダムの市街搪大（2０ 世紀） 
現した。その北侧では1865〜1872年、北海運河の開 削と同時に幅の広いI J川の埋立が実施された。こ のような大規模な土木事紧纥蒸気力が動力として使 用されるようになって初めて可能になった。1876年 北海连河が開通し、アムステルダムと北海が直結さ れた。この結果、アムステルダム港は再び発屡し始 めた。

また、1839年にオランダ初の鉄道がハーレムに敷 設されて以来、オランダ国内で鉄道は都市の境界を 越える交通手段として急速に発展し、1889年にアム ステルダムの中央駅が竣工した。

1870年からアムステルダムの産業活動は急速に発 展し、これに伴う各種建筑活動の結果、市域が拡張 していった。1870年から1900年にかけて人口は 255,000 人から 511,000 人に急增し、900ha の新しい 市街地（built-up area)が出現している（図 7, 図 8)。

すでに1848年に城壁は旗去され、それに続いて入 市税が廃止され、城壁の外への市街地昖㖘が可能に なった。こうした中で17世紀以来、約 250年ぶりに 計画的な拈街地拡張が立案された。1866年、アムス
テルダム市の建築技師長 (2) J.G.van Niftrik は旧 城壁の外周にベルト状に汸街拡張計画を立案した

(図 9)。

この㖕画は学慟者住宅、庭園住宅、プロムナード、 公園を配置しており、幾何学的な街路と広場のデザ インにはオスマンのパリ改造計画の影響がみられる。

しかし、この Niftrikプランは柆参会が承認せ ず、実行されなかった。iftrik プランが否定され た理由は第一に、アムステルダム中央臤を中央政胕 が決定済みの地点（現在の駅の位置）に置かず、南 東の新市街にもって来たこと、第二に、本当の理由 として、都市計画実施に伴う土地収用・所有権の栘 転が既存の法規にそぐわないと見做されたことであ つた。

1877年、アムステルダム公共專業局長 Dr.J.Kalff とJ.G.van Niftrik は改定した案を作成し、今度は 市参事会から承認され、実行に移された。1877年の Kalf f プランは既存の農地所有権の境界を尊重して 搪張洒街地を計画したため、市参事会の反対を受け なかった。1866年の Niftrikプランと比べると公園 面積は縮小している。既存の水路は埋立られ、街路

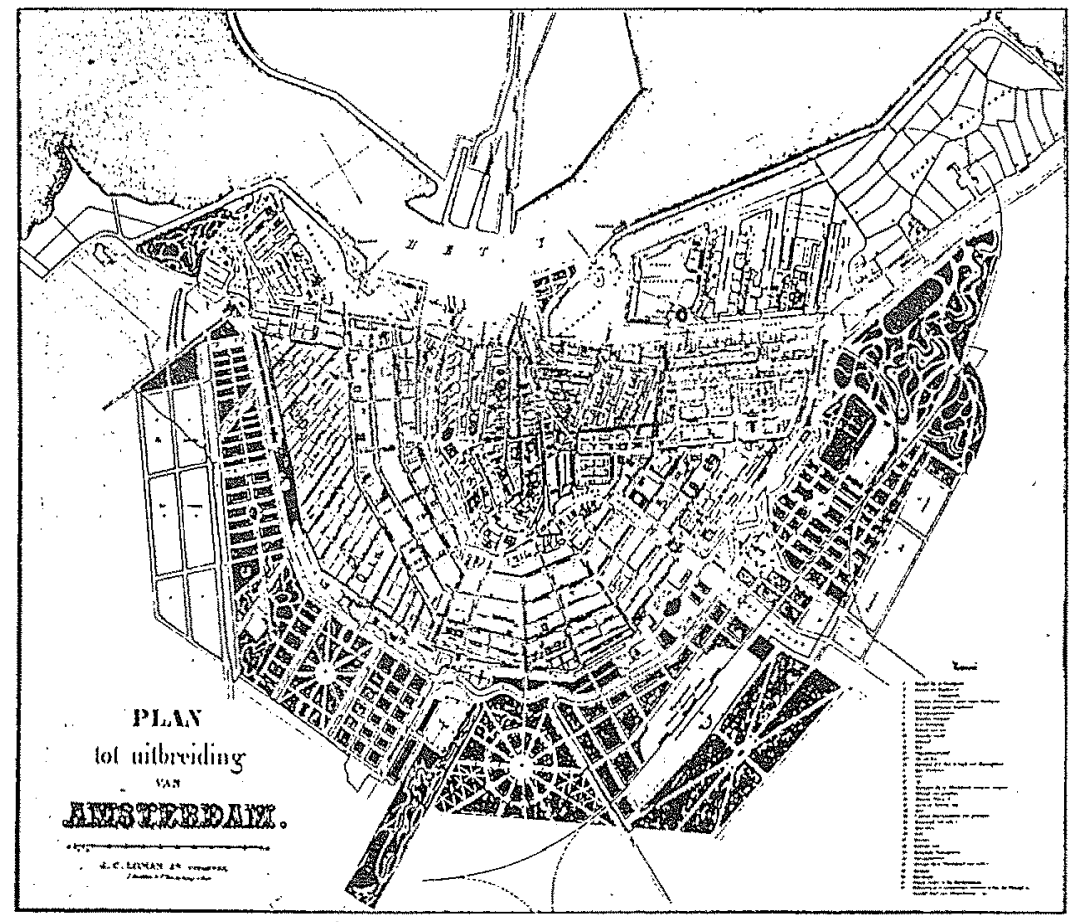

图９1866年のアムステルダムの市街抬張計画 (Van Niftrik のプラン)
図の古下に中央駅、 図の右、左上、左下、下に 公園を配置している

The extension plan drawn up by cily architect J.G. van Niflrik in 1866 , with the Central Station in the bottom right-hand comer. This plan was never execuled 
となり、拡張捅街地には集合住宅が高密度に建設さ れた。

アムステルダムでは約 200年間の経済停㳪の間、 既成沛街地では借家への投資がほとんよ゙なされず、 老朽化が進み、スラム化していだ。1874年に不槛颜、 金融を市当局は認め、1900年にかけて新市街に大量 の住宅供給が行われ、住宅事情に苫しんでいた旧市 街の過剩人口の受け攻となった（Kalff プランによ る拡張市街地は今日、19世紀べルトと呼ばれている)。 1874〜1900年の住宅供給は狭い土地にできるだけ 多くの住宅を詰め込むやり方であり、建筑法規も不 十分であった。そのため、住宅の質は少っていた。 建主は道路费を負担するだけで、住宅街とメインス トリートとの速絡は何も考えず、與計画であった。

一方、1850年代より労働運動が勃興し、その政治 的発言力は鮥視できなくなってきた。この結果、社 会政策として住宅供給、住環境の整備が必琹とされ るようになってきた（図10）。

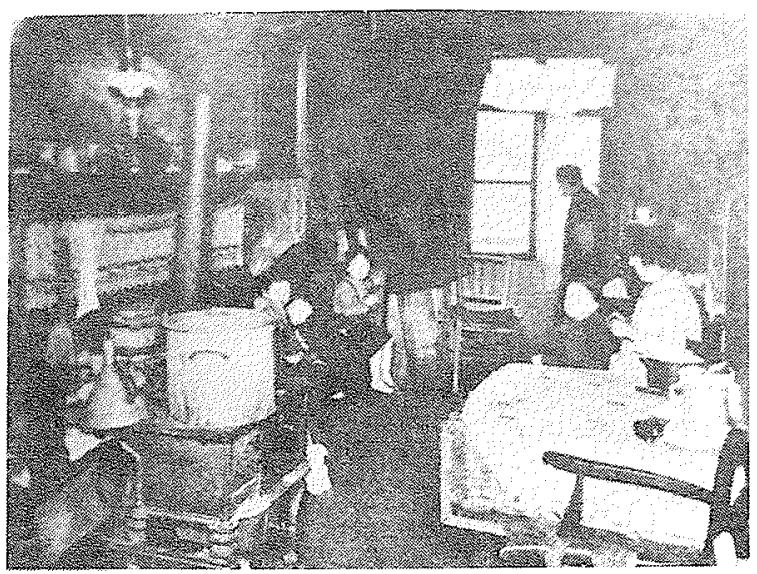

This photograph, which

出所 文献 6 was published in 'Het Leven' in 1928, showes the interior of a dzeclling in Korte Keizcrsstrat in which a man, bis wiff, their four children and a grandfatber shared a single room measuring 12 square metres.

図 10 アムステルダムの労働者の住宅事情 $\left(12 \mathrm{~m}^{2}\right.$ に 7 人家族が居住している)

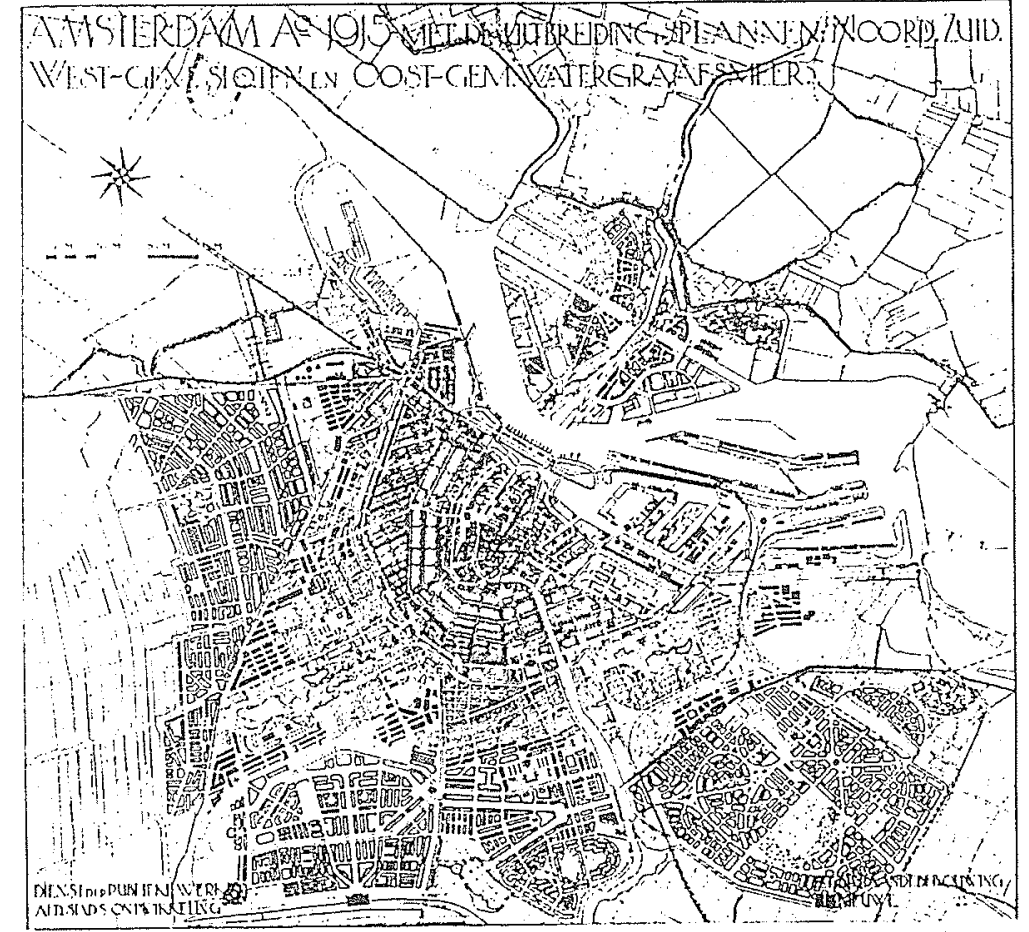

Amsterdam 1915, with expansion plan Berlage

图１１１９１５年のアムステルダムの市街抬張計画 (Berlage のプラン) 
19世紀末になると市参事会は都市のインフラ整備 に自ら㥽任を負っていることを珰めた。1896年、市 参事会は郊外に取得した土地は売却せず、貨貸とし きびしい建築規則を適用する方針を決定した。また、 公共交通 (路面電車) 、電気とガス会社も市営とし た。そして1901年、住宅法(The Housing Act) を制 定し、労働者住宅の改良に乗り出したのである。

4 1917年のベルラーへの南郊計画 (Plan “Zuid”) 1901年に公布された住宅法はオランダで初の都市 計画法規であった。住宅法という名の示すとおり、 この法律の目的は労傎者住宅の改善を目的としてい たか、、住宅改良・住宅供給に必要な用地を取得する ために、市当局に都市計画実施の権限を付与してい た。この結果、住宅法はオランダ初の都市計画法と して位置付けられている。1901年以前は、都市改造 ・都市拡張のコントロールは沛当局と建築当事者の 任意協定に任されていた。

1901年の住宅法は、住宅政策が都市の重要な社会 政策であると見做されたことを示している。そして すでに1896年に決定された土地政策（取得用地の賏 貸方式、lease-hold system)と相まって、住宅開発
に公共側が強力なコントロールを発揮する政策を打 ち出したことを示している。住宅法制定の結果、市 参事会は今後の都市の成長と発展を計画する義務が 生じた。公鼻衛生の改善によって出生・死亡率は変 化し、工場の都市への集中はいっそうの人口增加を もたらした。アムステルダムの人口は1900年から 1930年にかけて 52.0 万人から 75.7 万人急增した。 しかし、都市の発展は公共のプログラムのもとにコ ントロールされており、無秩序なスプロールが生じ た訳ではない。

1902年、アムステルダム市当局はオランダを代表 する建築家ベルラーへ(Pr. H. P. Berlage) ${ }^{(3)}$ にアム ステルダム全市の拡張計画の立案を委啒した。1902 年にベルラーへが一旦、立案したプランを市当局は 実行せず放置していた。その後、1915年、ベルラー へは改定案を作成した。それは幅員のランクに応じ た街路網を配置し、住宅の形状、オープンスペース 等を工夫し、それらをすべて丁寧に書き込んだ精緻 で造形的にも美しい見事なプランであった（図11）。 この1915年のベルラーヘのプランのうち南郊の市街 昖張計面 (The Extension plan “Zuid”)は、1917年 枋参等会によって承琹され、実行に移された(図12)。

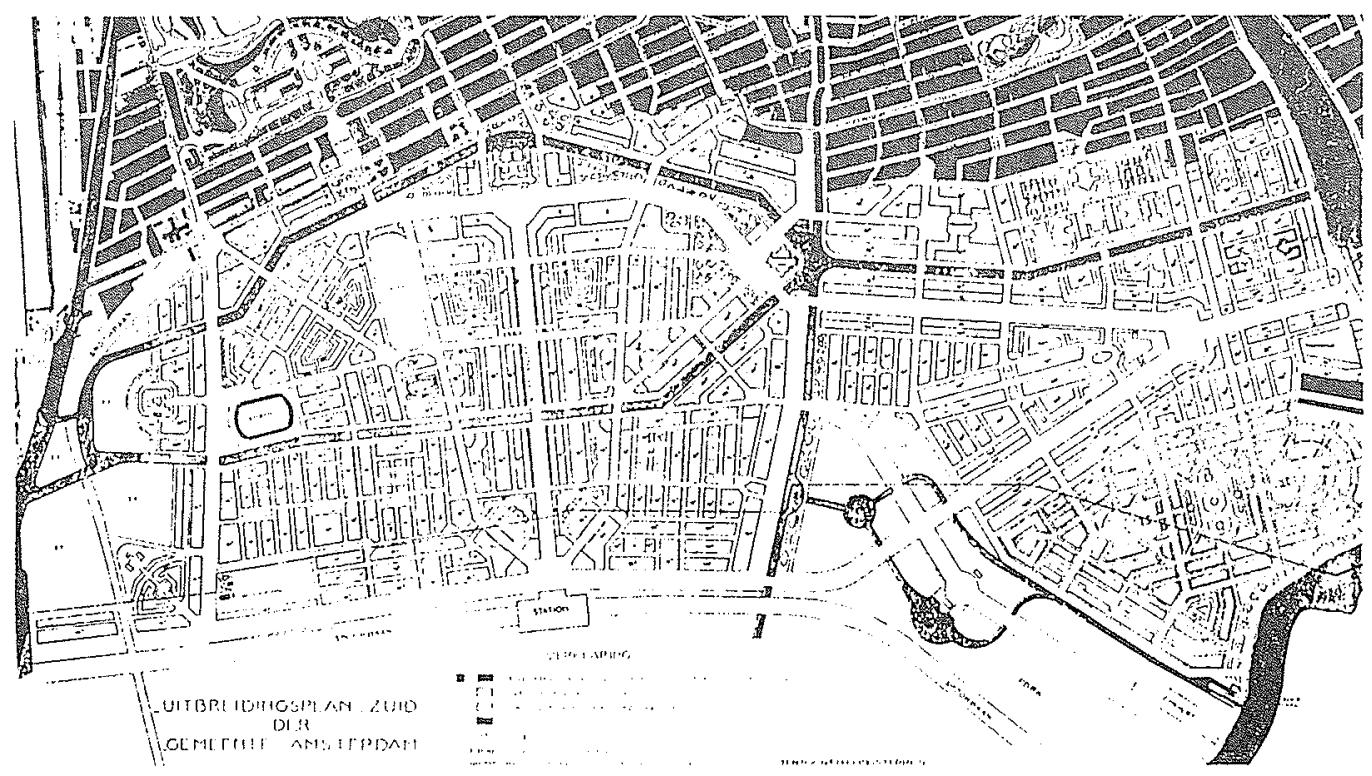

図121917 年に市参事会が承認したアムステルダム南郊市街拡張計画 (Berlage 設計のPlan "Zuid") 出所文献 2

The Extension Plan "Zuid" by H.P. Berlage, which was approved in 1917 


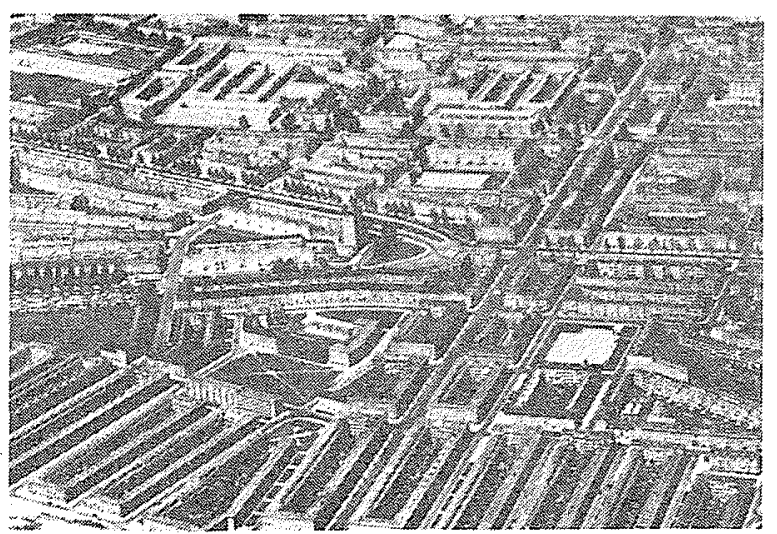

出所 又献11

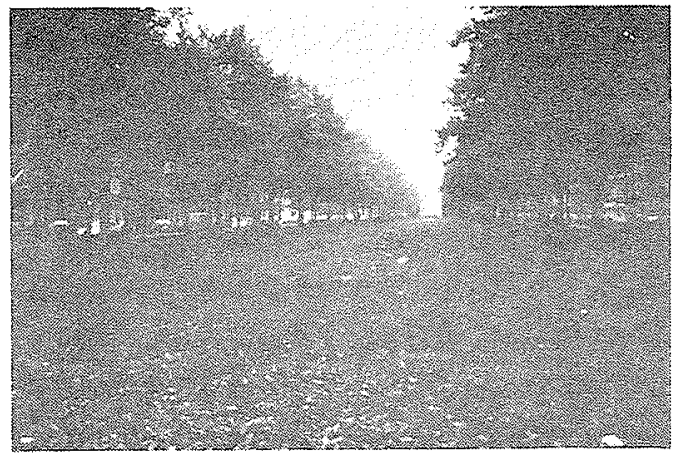

筆者撮影 (1987年)

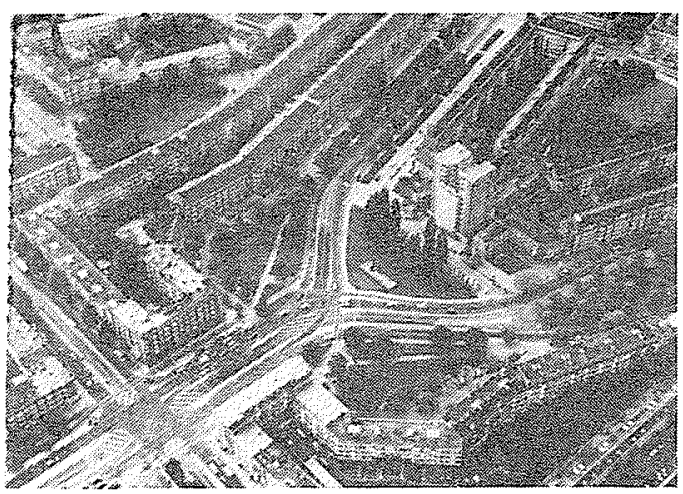

出所 文献 2

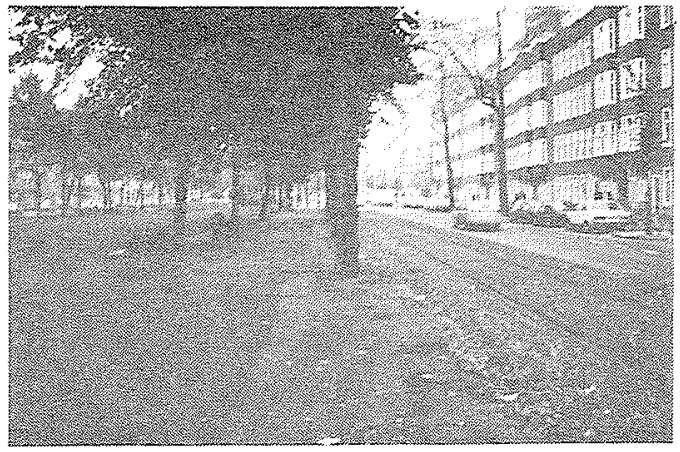

筆者撮影 (1987年)

図 13 アムステルダム南郊 (Plan "Zuid")地区の現況

Y字形の広幅員街路が地区全体の幹線街路となっている。 広幅員街路には路面電車が走り、路面電車政を含めて、広幅員の グリーンベルト（モール）が1直線に綄いている。

The Victorieplein, where three wide avenues meet near Amslerdam's tirst lower-block, is one of the more striking features of the "Plan Zuid"

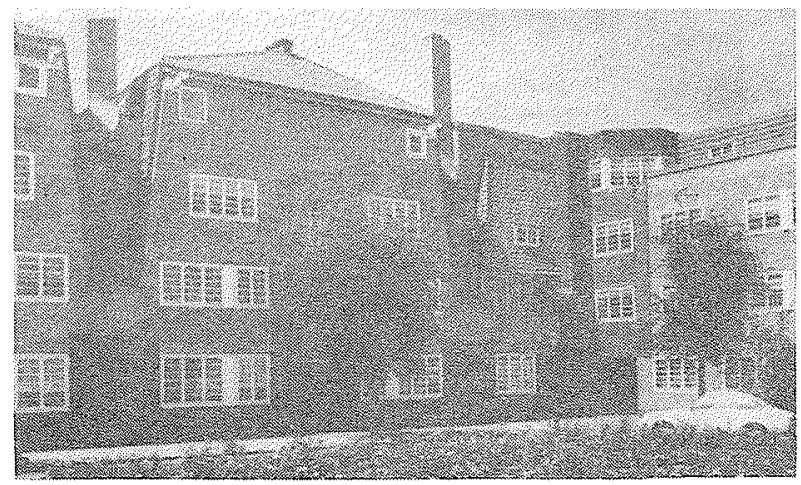

Houses on the

Henriette Ronnerplein, by archifect M. de Klerk

Some examples of archilecture of the "Amslerdamse School" in the "Plan Zuid" area
TENEMENT HOUSES BELONGING TO THE PUBLIC UTILITY SOCIETY AT AMSTERDAM AND ERECTED IN 1922-23. Archilect: P. KRAMER

図14 アムステルダム南郊 (Plan "Zuid") 地区の集合住宅 (アムステルダム派の建築) 
日本の公共住宅政策が陳府な箱形の公団住宅の団 地をつくり出したのに対して、ベルラーへは実に魅 力的で美しい住宅地をつくりあげている。ベルラー へのPlan “Zuid” は社会政策の目的を笑現しながら 一方で美的観点を追求した都河計画として20世紀の 近代都们計画の中でも特籍すべき洒値を持っている。 広幅員のブールバールを配䁌し、幹線交通を美的 に処理し、ビスタには公共建築を膡いている。集合 住宅はさまざまな階層のためのタイプが用意され、 すべての階層の人々が同じ住環境を享受できるよう 集合住宅群、公共建築、広場、区画街路を巧みに、 またリズミカルに配置している（図13，図14）。
Plan “Zuid”地区の集合住宅群の建設のために市 当呞は The Public Utility Housing Society を設 立し、住宅の設計・施工を行った。この協会はミケ ル・デクラーク (Michel de Klerk)、ピエト・L・ クラメル (Piter Lodewijk Krammer) らの建築家に 大きな権限を与え、集合住宅の建設を進めた。

南郊 (Plan “Zuid”地区) や北西郊の新市街の集 合住宅の建設のため、1920年代活躍した建築家を建 築史ではアムステルダム派 (Amsterdam School) と 呼んでいる。その特長はオランダ現地産のレンガを 屋根、壁面に多用し、自由奔放なファサードを採用 していることである(図14)。
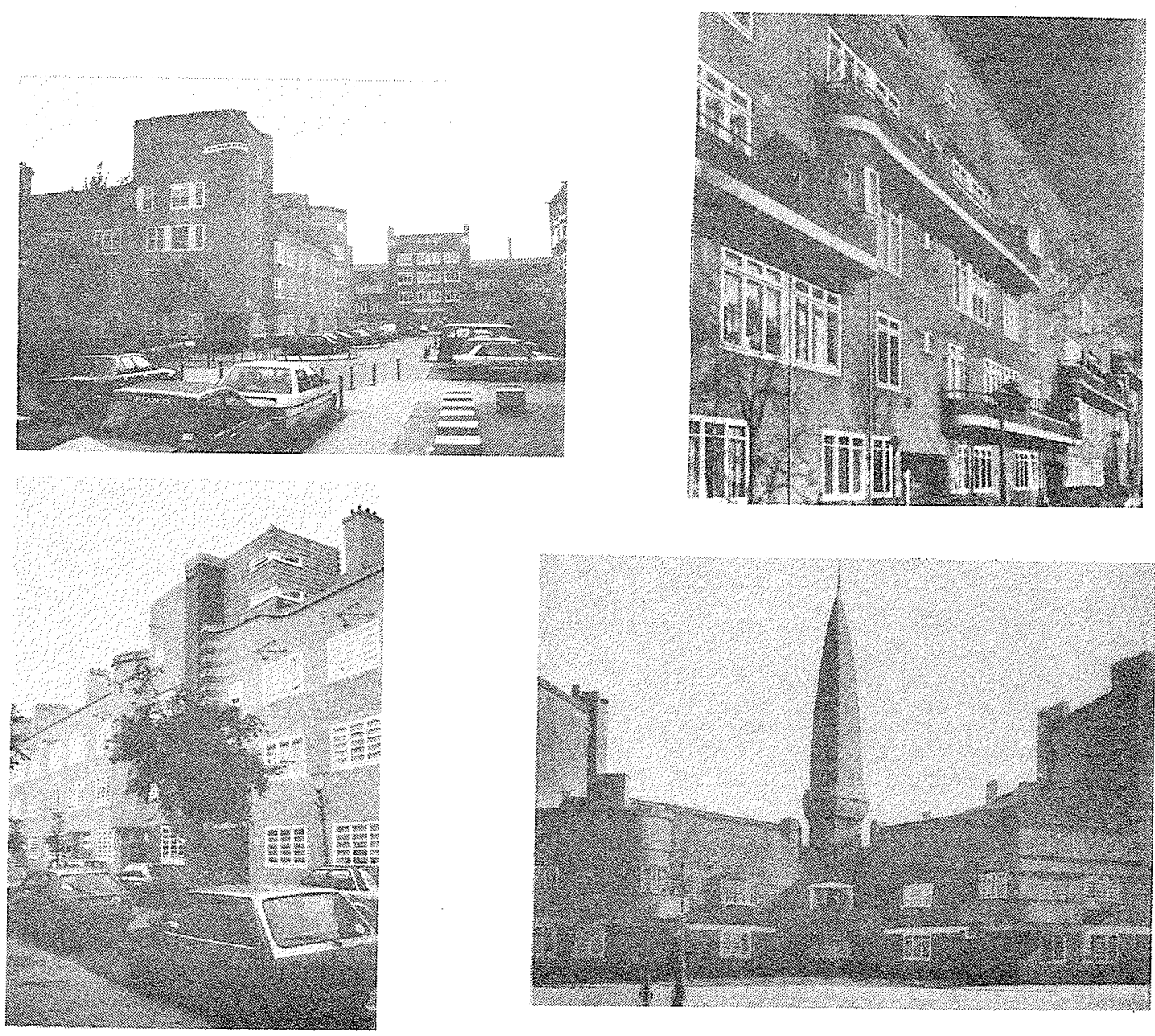

図１５アアムステルダム派の集合住宅（右下が北西郊地区、それ以外の 3 枚は南郊地区） 左上は Kramer、右上・右下は De Klerk の設計。 
都市デザイン、景観設計の観点から今日、ベルラ 一への Plan “Zuid”から学ぶべき点が多い。Plan “Zuid”を可能にした前提条件は第一に住宅法、第二 に土地の公有化 (Lease-hold system)であり、これ に加えてベルラーヘ、デクラークら建築家のすぐれ たデザイン、そしてこのデザインを引き出した当局 の姿勢にあったということができる。

\section{1935年の総合都市計画と結び}

Plan “Zuid”にもとづく南郊の開発が進められて いる最中の1924年、国際都市計画・田園都沞協会 （1913年に田園都市運動の創始者ハワード莭が設立

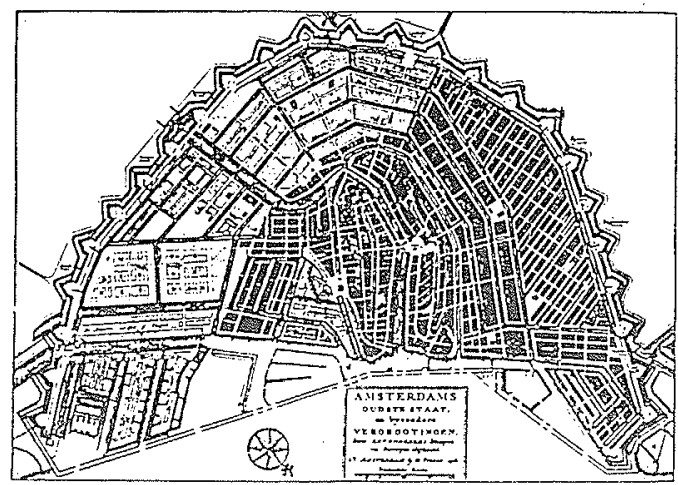

$$
\begin{gathered}
\text { Conférence Internationale } \\
\text { de l'aménagement des Villes Amsterdam } 1924 \\
\text { DEUXIEME PARTE } \\
\text { COMPTE RENDU }
\end{gathered}
$$

COMPTE RENDU
$\begin{gathered}\text { Internationale } \\ \text { Städtebautagung Amsterdam 1924 } \\ \text { BAND II } \\ \text { BERICHT }\end{gathered}$
Town Planning Conference Amsterdam 1924
PART II
REPORT

Iaternationaal

Stedebouwcongres Amsterdam 1924 DEEL II

図161924年のアムステルダムで開催された 国祭都市計画会詳の議事録（䇝者所蔵）

（表紙の地図は１６６３３年のアムステルダム）
した団体、現在の I F H P の前身) の国際都市計画 会議がアムステルダムで開唯されだ。この会議は近 代都市計画史上、有名な地方計画（Regional Plan） の 7 力条の決議（大都市の膨張抑制、市街外周のグ リーンベルトの設置、衛星都市の建設など）を採択 した。これ以降、日本も含めて先進国の都市計画は 大きく方向転換した（図15）。

1928年、市助役 F.M.Wibaut のイニシアチブのも と公共事業局に都㧍計画部が新設され、総合都市計 画（i域全体を計画対鱼区域とする）の立案が開始 された。この計画は1935年に沛参事会によって承認 された（図16）。

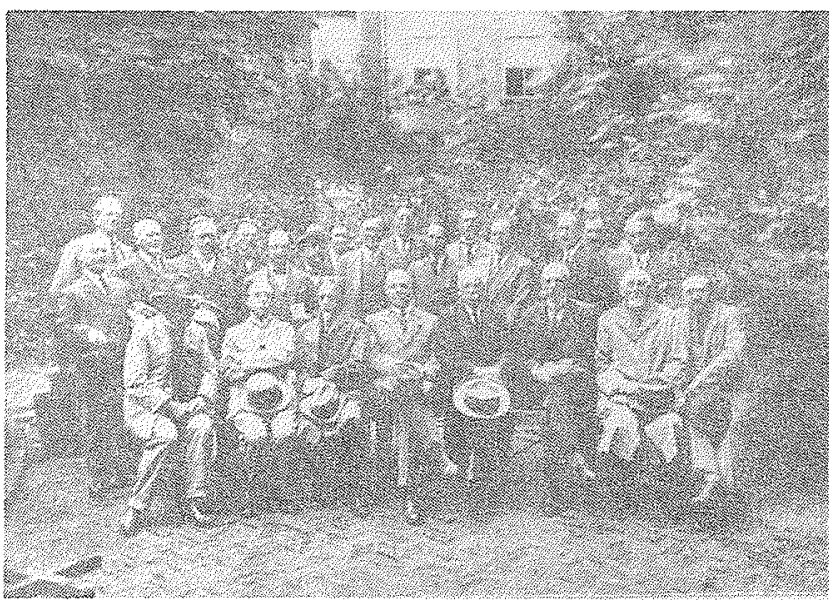

图171924 年当時の国際都市計画・田園 都市協会の理事（前列の左端が Berlage 博士、その左が Unwin 博士、 2 人おいて会長の Howard 梸) 文献 4

Members of the Council of the International Federation for Town and Country Planning and Garden Cities

Sealed: Dr. 1f. P. Berlage, Dr. R. Unwin, Senator Vinck, Dr. D. Hudig, Ebenezer Howard, A. Bruggeman, Sir John Sulman, Qustav Langen. Sisnding: —- Dr. Hans Kamplfmeyer, Bernhard Kamplfmejer, Dr. E. Böök, Adotl Otto Carlos M. della Paolera, Lawrence Veiller, Dr. Otakar Fierlinger, C. B. Purdom, H. Chapman; Clarence S. Stein, Yrgo Harvis, O. L. Pepler, O. M. Harrls, Sir Theodore.Chambers, Kal Hendriksen 


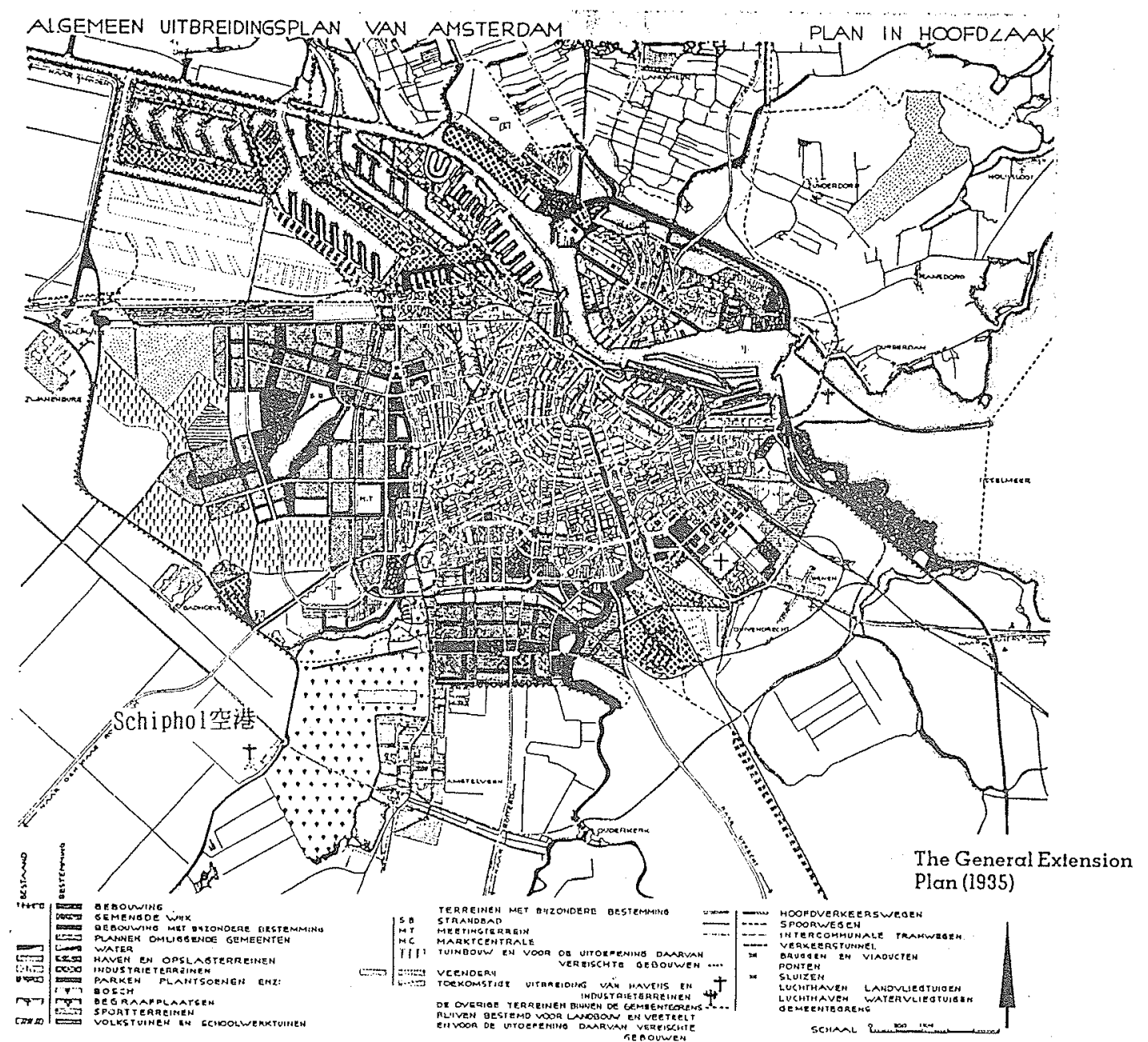

図181935 年のアムステルダムの総合都市計画 北西に港湾・倉庫・工業地鱼、西には人工湖を中央に置いて公園之住宅地、 南西にSchi phol空港と森林、南東に住宅地が配置されている。 1958年、1959年に北郊 (工業地帯)、南東郊外（大規模二ュウータウン）が 追加され、外郭の高速道路・高速鉄道が整備され、今日に至る。

この計画は 2000 年の人ロフレーム (96万人と想定) をもとに雇用、都市の機能を検討し、土地利用、都 市施設を総合的に計画している。港湾、空港、大公 橉、工場地帯等を配置し、土地利用のゾーニングを 行っており、まさしく現代の都㭪計画（マスタープ ラン) の手法が採用されている。

その後、アムステルダムはこの1935年の計画に基 づいて約40年間、都市建設が続けられてきた（1958 年、1959年に北郊、東南部の開発計画が追加されて (る)。この結果、スキポール空港や郊外の大公園 (約900ha)が整備され、住宅用地（1地区は約 1 万 戸)が計画的に建設されてきた。
このようにスプロールなしに計画的に住宅供給と インフラ整借を進めてきたことは評洒してよい。し かし、1940年代以降、建設された住宅団地は確かに さまざまな都市施設は整っているものの、1920年代 のアムステルダム派の集合住宅の街並みのような人 を引きつける魅力に欠けているのはどうしてであろ うか?

1930年代以降、欧米や日本の機能重視の都市計画、 ニュータウン建設が忘れ去ってしまった都师の造形 美の亚値を改めて教えてくれるのが、1917年のPlan "Zuid"であるといえよう。 
注

（1）南郊市街拡張計画の名称について、アムステル ダム市都伂計画局はオランダ語、英語で次のよう に記している(文献 1)，2）〕。 Het Uitbreidingsplan-Zuid van H. P. Berlage, vastgesteid in 1917.

The Extension Plan "Zuid" by H. P. Berlage, which was approved in 1917.

Zuidとはオランダ語でSouth(英語)、Sud(独語) を意味する。

また文献 3）は、The Southern Extension of Amsterdam;. Planner : II. P. Berlage と記して おり、文献 4) は次のように記している。

Amsterdam a acquired large tracts of land......, especially in the southern part of the town to carry out an extension scheme projected by Dr. Berlage.

（2）J.G.Van Niftrik の瞕について文献 2)，8）は City architectと記している。これを仮に建築技 師長と訳した。

（3）ヘンドリック・ペトルス・ベルラーヘ

Hendrik Petrus Berlage (1856-1934)。 それまでの様式建築を克服し、自国の伝統と風土 に合った建築をめざしたオランダの近代建築の祖 である。レンガ壁の使い方は後にアムステルダム 派の建築の基をつくった。
参考文献

1) Dienst Ruimtelijke Ordening van Amsterdam, "De Ruimtelijke Ordening in Amsterdam", Amsterdam, 1983.

2) Amsterdam Physical Planning Department. "Amsterdam, Planning and Development". Amsterdam, 1983.

3) Arnold thitlick, "European Architecture in the Twentieth Century" , London, 1950.

4) International Federation for Town and Country Planning and Garden Cities, "International Town Planning Conference Amsterdam 1924 . Part II Report " , Amsterdam 1924.

5) Amsterdam Road voor de Stedebouw, "Algemeen Ui tbreidingsplan Amsterdam 50 Jaar 1935/1985 " , Amsterdam 1985.

6) Dedalo Carasso, "A Short Hisory of Amsterdam" , Amsterdam Historical Museum, 1985.

7) “Amsterdam School” , Amsterdam Historical Museum, [unknown].

8) Guus Kenme, "Amsterdam Architecture" , Amsterdam, Uitgeverig Thoth, 1987.

9) Hans Laumanns, Amsterdam - An Example of Open Space Orientated Urban Planning?, " Garten und Landshaft" $1 / 84$.

10) A.M. van de Waal, "Amsterdam, Toen en Nu" , Amsterdam, H.D.Pfann, 1974.

11）レオナルド・ヴェネヴォーロ著、佐野敬彦・林筧治 訳、第 $3 、 4$ 巻 相模書房、1983年。

12）ボエルヂ「欧米各国に於ける都市計画亚に地方計画 に関する実行上の難点及其の打開策(5)」『都市公論』 13巻 1 号、1930年。

13）【新建築】1991年1月蹦時增刊（建築20世紀 Part I) 。 